\title{
Steroidogenesis and the initiation of parturition
}

\author{
Alan J. Conley ${ }^{1}$ and Lawrence P. Reynolds ${ }^{2}$ \\ ${ }^{1}$ Department of Population Health \& Reproduction, School of Veterinary Medicine, University of \\ California, Davis, CA 95616; ${ }^{2}$ Department of Animal Science, Center for Nutrition and Pregnancy, \\ North Dakota State University, Fargo ND 58108
}

\begin{abstract}
Overview
One of the most fundamental axioms of mammalian reproduction is that pregnancy requires the support of progesterone without which it cannot be established or maintained. Though this basic physiological tenet was accepted long ago, major gaps in our understanding of the physiology of both pregnancy and parturition remain which hamper our ability to solve clinically and agriculturally significant problems such as low fertility, fetal growth restriction, preterm birth and poor neonatal outcomes. The historical reliance of our understanding of both pregnancy and parturition on this single hormone, and how it has been measured in the vast majority of studies, may represent a tangible weakness and impediment to progress. Other weaknesses include a desire to fit all species into a unified paradigm, and a reluctance to accept that physiological processes regulated by progesterone or other progestins in different tissues might vary in reliance on classic (nuclear receptor) versus other, non-classical mechanisms of action. The relative importance of these distinct response pathways in certain cells or tissues also may differ across species, as does so much of basic reproductive physiology. It is well known that certain species are reliant on luteal function throughout gestation, whereas the placenta subsumes endocrine support in others (Geisert \& Conley 1998), yet progesterone alone is still believed to be the single common element. As radical as it might seem, however, progesterone may not be the single common hormone of pregnancy in mammals.
\end{abstract}

Combine these caveats with the fact that only a relatively small number of the 5,500 or so species of mammals have been evaluated throughout pregnancy, and it seems clear that our understanding of the role of steroids in pregnancy and parturition is poor at best. In this review we will address steroidogenesis and the events that bring about parturition, but will do so in an attempt to highlight potential weaknesses in the commonly held assumptions that have become the basis for designing and interpreting studies on the maintenance of pregnancy and the initiation of parturition in domestic species. We would like to think that the pioneers of steroid biology would welcome such a discussion, and might even wonder with all the studies conducted, and/ or modern methodologies applied, why we have made so little progress in addressing this fundamental question. 


\section{Brief historical perspective}

A discussion of the endocrine control of pregnancy and parturition seems incomplete without reflecting on the history of how progesterone was identified and its role defined, because much of our current understanding is founded on assumptions derived from those foundational discoveries. If it was Berthold and Brown-Sequard that gave life to the notion of internal secretions, it was the work of many others that began to clarify the complexity of the sex steroid hormones and their actions. As Marshall put it in 1922, almost a century ago, "We are thus forced to conclude that the phenomena of pregnancy and parturition are brought about by chemical stimuli acting through the blood-stream (Marshall 1922)." This basic understanding of pregnancy and parturition were crucial in establishing the existence of the progestogenic class of steroid hormones, specifically as it relates to the endocrine function of corpora lutea and the placenta. The effects of progestins on the endometrium led ultimately to the chemical identification of progesterone itself. Specifically, isolation of bioactive extracts from corpora lutea, was followed by the purification, crystallization and eventually the determination of the formula of progesterone, all of which was accomplished through the combined efforts of several groups between 1929-1934 using in vivo bioassays evaluating endometrial responses (Corner 1946).

In fact, several bioassays were developed and used during that period. Most, like the CornerAllen assay which used adult female rabbits (Corner \& Allen 1929), or the Clauberg-McPhail assay in immature, estrogen-primed rabbit does (McPhail 1934), assessed the degree of endometrial proliferation or decidual cell response (Astwood 1939) induced by compounds administered by injection (Glasser 1975). Studies on the relative potencies of endogenous pregnanes were few. Instead, the search for synthetic, orally active progestins refocused investigators toward developing therapeutic compounds. However, as some have pointed out, the most reliable and relevant bioassay is the maintenance of pregnancy, and many of the synthetic progestins that stimulate endometrial development may not be capable of doing so (Glasser 1975). More importantly, few endogenously synthesized pregnanes (putative progestins) have been tested for their ability to sustain pregnancy. Studies such as these are particularly difficult to conduct in large animal species not only because of the doses required but also because of the relatively long gestation length. Therefore, in contrast to the multiple steroids populating the estrogen, androgen and corticoid classes, after eight decades the progestin class still contains only a single, physiological steroid, progesterone, whose bioactivity had been definitively established.

\section{The focus on progesterone as the sole physiological progestin, and the potential existence of other bioactive progestins}

How plausible is it that progesterone is the only physiological progestin in mammals? As early as 1959, Short commented that circulating progesterone concentrations in pregnant mares were surprisingly low, $<4 \mathrm{ng} / \mathrm{ml}$ (Short 1959). This landmark observation was confirmed and extended decades later by Holtan et al. (Holtan et al. 1975; Holtan et al. 1991) and others (Ousey et al. 2005), who showed, ultimately using gas chromatography mass spectrometry, that progesterone concentrations in mid to late equine gestation were $<0.5 \mathrm{ng} / \mathrm{ml}$, including in the circulation of the fetal foal (Ousey et al. 2003). Conversely, circulating concentrations of $5 \alpha$-reduced metabolites like $5 \alpha$-dihydroprogesterone (DHP) were very high (Hamon et al. 1991; Holtan et al. 1991; Ousey et al. 2003). Moreover, horses are not unique in this regard - very low to undetectable plasma concentrations of progesterone are found in zebras (Klima et al. 1999), elephants (Hodges et al. 1997) and the rock hyrax (Kirkman et al. 2001). 
Importantly, DHP has also been shown to compete equally with progesterone for binding using equine endometrial (Jewgenow \& Meyer 1998) and mammary (Chavatte-Palmer et al. 2000) extracts, endometrial extracts of the elephant (Meyer et al. 1997; Jewgenow \& Meyer 1998; Greyling et al. 1997) and rock hyrax (Kirkman et al. 2001), and to lesser, more variable degrees in other species (Jewgenow \& Meyer 1998). Unfortunately, attempts to demonstrate bioactivity of DHP on equine myometrial contractility were unsuccessful, but progesterone was no more active in those assays (Ousey et al. 2000). Thus, for some time alternative or additional endogenous pregnanes with progestational activity have been postulated to exist but never confirmed. Consequently, studies on pregnancy and parturition have remained focused on measuring progesterone, most without some form of chromatography and using immunoassays with primary antisera that necessarily cross-react (Behrman 1988) with multiple pregnanes of unknown bioactivity and therefore unknown significance.

Recent efforts in one of our laboratories have attempted to build on the pioneering studies in equine pregnancy cited above (Short 1959; Holtan et al. 1975; Holtan et al. 1991; Jewgenow \& Meyer 1998; Meyer et al. 1997), by re-examining the bioactivity of DHP in vivo and in vitro (Scholtz et al. 2014). We first demonstrated that DHP can induce equine endometrial growth and profoundly stimulate endometrial expression of the progesterone-responsive genes uterocalin (Crossett et al. 1996; Crossett et al. 1998) and uteroglobin (Muller-Schottle et al. 2002; BeierHellwig et al. 1995) in ovariectomized mares (Scholtz et al. 2014). Interestingly, Kontula et al. also reported in rabbits that DHP was highly uterotropic if administered locally into the uterus (Kontula et al. 1975), but not if administered by injection (Rahman et al. 1975). Second, we showed that DHP (but not vehicle) could maintain equine pregnancies with normal fetal development to day 27 after progesterone was withdrawn by inducing luteal regression on day 14 (Scholtz et al. 2014). Third, we demonstrated using a reporter assay in vitro [MMTV-luciferase in HepG2 cells, co-transfected with expression constructs encoding either equine or human progesterone receptor (PR)] that DHP activates the equine PR with equal potency and efficacy to progesterone itself and does so at concentrations seen during the luteal phase and second half of equine gestation (Scholtz et al. 2014). Although exhibiting one-fifth the biopotency of progesterone in terms of activating the human PR in our studies (Scholtz et al. 2014), DHP exhibits high affinity binding to human myometrial extracts (Kontula et al. 1975), and was equally efficacious in our in vitro bioassay at concentrations found circulating systemically in women in their third trimester (Milewich et al. 1975; Hill et al. 2007). The binding of DHP to the ligand-binding domain differs among the PR of various species, with binding of DHP to endometrial cytosolic extracts from elephants and horses equal to or greater than that for progesterone (Wierer et al. 2012), consistent with our in vitro bioactivity data (Scholtz et al. 2014). This is an important, if simple, concept. Steroids do not themselves evolve, and as conserved as their actions may be across species, the steroid receptors do and have evolved to respond to different endogenous agonists (Baker 2001; Baker 1997; Baker \& Uh 2012). Thus, we have answered our question whether progesterone is the only potent, physiological agonist in the progestin class, and indeed it is not. It seems to us equally likely that DHP is not the only endogenous progestin in mammals, even in species like the horse where DHP exhibits bioactivity comparable to progesterone (Scholtz et al. 2014). The challenge then is to define relative biopotencies of DHP and various other potential progestins across species using species-specific bioassays and measuring endogenous concentrations by appropriately specific methods.

Refocusing attention on DHP as a bioactive progestin of physiological significance, in some species at least, immediately implicates the $5 \alpha$-reductase enzyme system as important in the physiology of pregnancy and perhaps even the initiation of parturition. Evidence suggests that 
of the two major isoforms, the $5 \alpha$-reductase type 1 isozyme is likely to play the more important role in conversion of progesterone to DHP than is the type 2 isozyme, and our studies in horses support this. There was a clear predominance of type 1 over type 2 expression in equine endometrium and chorio-allantois from late pregnancy based on quantitative transcript analysis (Scholtz et al. 2014). Expression of the type 1 isozyme predominates in human (Milewich et al. 1979) and mouse placenta (Mahendroo et al. 1996) also, and in human corpora lutea as well (Haning, Jr. et al. 1996). Moreover, since women with $5 \alpha$-reductase type 2 deficiency have normal concentrations of DHP (Milewich et al. 1995), $5 \alpha$-reductase type 1 isozyme alone is adequate and likely responsible for the synthesis of DHP. In contrast, sheep placentas at term appear to exhibit higher levels of expression of the $5 \alpha$-reductase type 2 than type 1 based on transcript analysis. Still, there is much greater expression of $5 \alpha$-reductase in caruncles (maternal) than in cotyledons (fetal placental; Fig. 1).
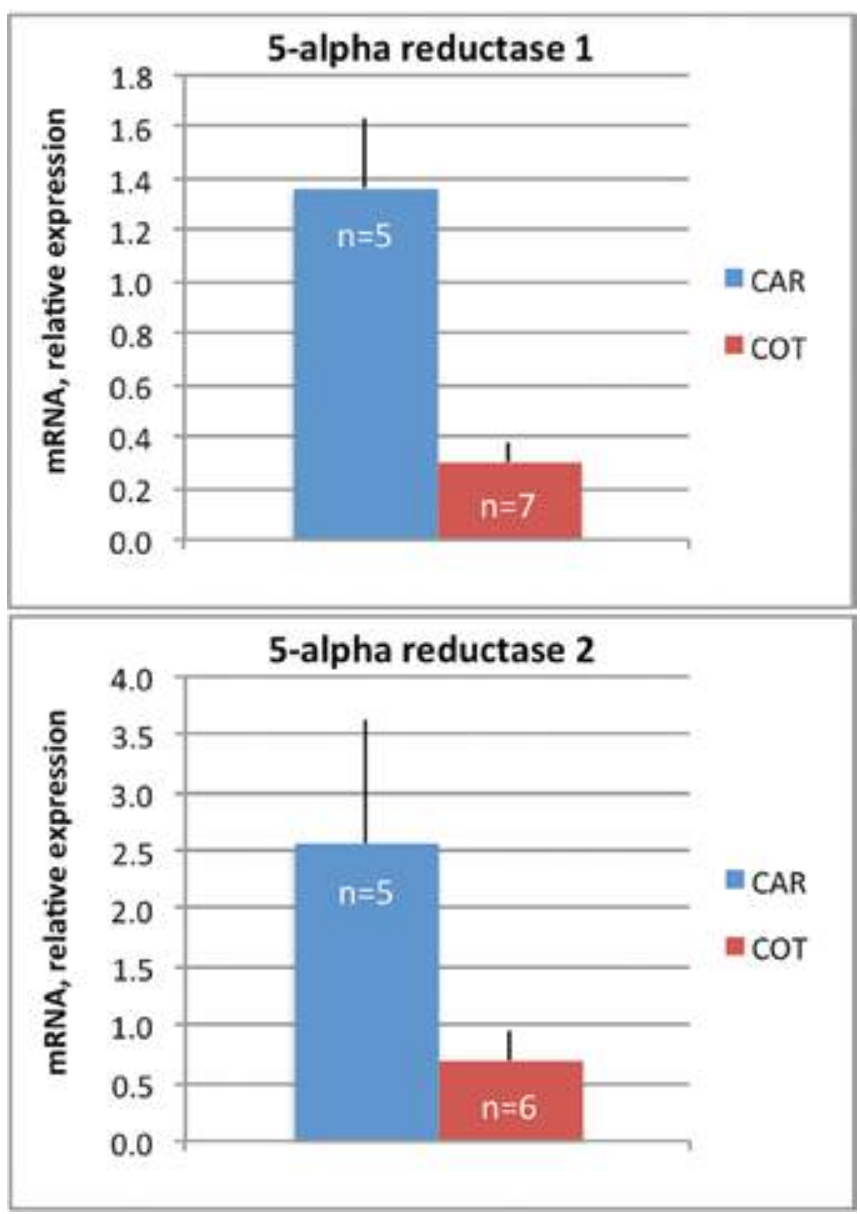

Fig. 1. Expression (qPCR) of $m R N A$ for $5 \alpha$-reductase isozymes 1 and 2 in sheep placenta at term (149.6 \pm 0.5 days). CAR $=$ caruncle $=$ maternal placenta; COT $=$ cotyledon $=$ fetal placenta. Two of the ewes had twin lambs; the remainder had singletons. LP Reynolds, AJ Conley, CO Lemley, KA Vonnahme, \& JS Caton (unpublished observations).

No known cases of $5 \alpha$-reductase type 1 deficiency have yet been found in nature (Griffin et al. 2001), even though there are many reported deficiencies of the type 2 isozyme in humans (Imperato-McGinley \& Zhu 2002; Wilson 2001; Wilson et al. 1993) and some likely in horses 
(Knobbe et al. 2011). However, the role of $5 \alpha$-reductase type 1 in pregnancy is suggested by the results of gene knockouts in mice which induces fetal death (Mahendroo et al. 1997) and impairs cervical ripening thereby preventing normal delivery (Mahendroo et al. 1999). In addition, in all species studied and reported to date, both isozymes metabolize progesterone more efficiently than testosterone (Wilson 1975; Russell \& Wilson 1994; Levy et al. 1995), suggesting that the $5 \alpha$-reductase type 1 and 2 isozymes are more adapted for progesterone metabolism than for testosterone. These observations are consistent with the notion that the physiological support of pregnancy, and perhaps even parturition, are in part influenced by the expression of $5 \alpha$-reductase type 1 , and the products of its enzymatic activity. For any particular species, the significance of $5 \alpha$-reductase in terms of a role in supporting pregnancy would depend crucially on the bioactivity of DHP at the PR. The existence of isoforms of the nuclear PR (Wei et al. 1988) is an equally important issue for consideration. Specifically, the results of human and rodent studies suggest that withdrawal might be associated with changes in the predominance of active and antagonistic PR isoforms, PR-A and PR-B (the "isoform switch hypothesis"; ISH), in addition to changes in cytokine and/or co-activator expression in myometrium and cervix (Mendelson 2009; Wagner et al. 2012; Fang et al. 2002; Merlino et al. 2007). Evidence for the existence of these PR isoforms has been obtained in cattle in early pregnancy (Slonina et al. 2012), but their possible involvement in functional progesterone withdrawal and the parturition cascade in ruminants or other domestic species remains unclear.

In addition to changes in PR isoforms, there are potentially other physiological effects of DHP or progesterone mediated through alternative transduction pathways. These 'other pathways' are often invoked to explain the rapid, non-genomic or non-translational effects of steroids, and indeed both classical and non-classical membrane-bound steroid receptors have been identified (Bernauer et al. 2001; Losel et al. 2003; Zhu et al. 2003; Karteris et al. 2006; Guerriero 2009). For example, membrane-coupled receptors responsive to progesterone (PGRMC1) have been found in myometrium of humans (Karteris et al. 2006) and other species (Slonina et al. 2012), and we have recently found expression of membrane estrogen and progesterone receptors in sheep endometrium and chorion during early pregnancy (days 14 through 30; (Reynolds et al. 2012a; Reynolds et al. 2012b)). How physiologically important these and other non-traditional pathways of progestin action may be is unknown. Attempts to demonstrate direct bioactivity of DHP on both human and equine myometrial contractility in vitro (Lofgren \& Backstrom 1994; Lofgren et al. 1992; Perusquia \& Jasso-Kamel 2001; Ousey et al. 2000; Mesiano 2004) have been equivocal. Progesterone itself was unable to influence equine myometrial contractility in vitro (Ousey et al. 2000), though it has been shown to be inhibitory in similar studies with rabbit (CSAPO 1956; CSAPO \& TAKEDA 1965) and human myometrium (Ruddock et al. 2008). The inhibition of human myometrial contractility by progesterone took hours to develop, and could not be blocked with a PR antagonist (Ruddock et al. 2008). Thus the effects of progesterone itself on myometrial contractility are neither immediate, as membrane receptor activation might be expected to be, nor are they likely mediated by classic nuclear PR and subsequent gene activation.

Even if DHP lacks direct effects on myometrial contractility, it may be a substrate for conversion to other bioactive pregnanes, which could occur in specific tissues and explain bioactivity in vivo that is not PR-mediated. Specifically, the $3 \alpha$-reduced metabolite of DHP, allopregnanolone, is a potent gamma-aminobutyric acid (GABA) type A receptor agonist and "neurosteroid" that potentiates GABA itself when present at even low concentrations (Reddy 2003). Allopregnanolone has been shown to reduce human myometrial contractility within minutes of addition to muscle strips in vitro (Perusquia \& Jasso-Kamel 2001). Similar relaxant effects have been reported for rabbit (Majewska \& Vaupel 1991) and rat (Putnam et al. 1991) myometrium. Moreover, the circulating concentrations of allopregnanolone, and several 
related pregnanolone isomers that increase during pregnancy (Parizek et al. 2005), decrease around the time of birth in women (Hill et al. 2001). Some of the effects of these neurosteroids may be central, mediated in part through oxytocin release (Leng \& Russell 1999; Brussaard et al. 2000); less is known concerning tissue concentrations derived by local synthesis from DHP. Thus, whether or not DHP is a physiologically significant agonist of the PR in species other than horses, metabolism of DHP to allopregnanolone may mediate a physiological role in pregnancy and parturition. In this regard, we recently have shown that mRNA expression of one of the enzymes able to convert DHP to allopregnanolone, AKR1C3, can be regulated sheep fetal hypothalamus during late pregnancy (day 130, approximately 0.9 of gestation) by maternal nutrient intake (elevated in restricted- vs. control-intake ewes) as well as maternal treatment with melatonin (decreased in melatonin-treated vs. control ewes; LP Reynolds, AJ Conley, JS Caton, KA Vonnahme, \& CO Lemley, unpublished observations). Levels of AKR1C3 mRNA also were present in sheep maternal (caruncular) and fetal (cotyledonary) placental tissues at parturition, but were 15-fold greater in maternal vs. fetal placenta (LP Reynolds et al., unpublished observations).

However it is that parturition is initiated, it must be timed so that the development of the fetus and its physiological preparation for birth is adequate to ensure the greatest likelihood of extra-uterine survival of the neonate. This requires dialogue between fetus and dam which, in the absence of neural connections, is necessarily hormonal in nature. The fetus either signals readiness for birth to the uterus, or the placenta signals impending delivery to the fetus. If successful, that dialogue culminates in maturation of the fetal adrenal cortex and the secretion of cortisol which is not only an element of the parturition process that is shared across all species studied, but is a prerequisite for neonatal survival. How fetal adrenal maturation and cortisol secretion is regulated remains one of the great mysteries of the physiology of birth (Liggins \& Thorburn 1994).

Even though the gland is capable of responding to ACTH stimulation, fetal adrenal cortex is poorly organized and functionally quiescent for most of pregnancy (Conley \& Assis Neto 2008). As term approaches however, the hypothalamic-pituitary-adrenal axis (HPAA) becomes activated (Wintour et al. 1975; Glickman \& Challis 1980), though this is less dramatic in pigs (Silver \& Fowden 1989; Conley et al. 1994) and difficult to demonstrate in the fetal foal (Silver \& Fowden 1994). In addition, although fetal adrenal activation is required for fetal maturation and neonatal survival, it is not an initiator of the parturition cascade in all species. Pituitary aplasia prolongs pregnancy and prevents timely parturition in cattle (Stormont et al. 1956; Kendrick et al. 1957) and ewes (Liggins \& Kennedy 1968; Liggins et al. 1967; Liggins \& Thorburn 1994), but not reliably in primates (Liggins \& Thorburn 1994; Novy et al. 1977; Mueller-Heubach et al. 1972). Therefore, there is clearly a spectrum across mammalian species with respect to the degree to which the fetal HPAA serves as the trigger for initiating birth even though fetal adrenal cortisol secretion is important for neonatal survival in all species known.

Little is understood about how activation of the fetal adrenal axis is regulated, but estrogens, prostaglandins and even neurosteroids have been implicated in providing both positive and negative stimuli (Conley \& Assis Neto 2008). As noted above, the fetal adrenal is capable of responding to ACTH throughout gestation, and cortisol secretion by the fetal adrenal provides feedback on the hypothalamus in human (Goto et al. 2006) and ovine (Unno et al. 1998a) pregnancy. The sustained increase in fetal ACTH and cortisol that occurs over the last week or two of gestation in sheep (Brooks et al. 1989) and cattle (Comline et al. 1974) suggests a change in sensitivity to feedback. Results of studies in pigs indicate that placental tissue, if left in situ and still viable after fetal demise, can prevent a single remaining, viable fetus from initiating its own birth (Stryker \& Dziuk 1975). Thorburn et al. postulated that the placenta somehow 
influences the sensitivity of the fetal hypothalamus to negative feedback as fetal cortisol increases at term (Thorburn et al. 1991), and hormonal signals from the placenta have also been shown to activate the fetal HPAA. Specifically, estradiol (Wood 2005) and prostaglandin E2 (Challis et al. 1976; Fowden et al. 1987) secretion has been shown to increase in the ovine fetus in late gestation, both stimulate ACTH release (Young et al. 1996a; Young et al. 1996b) and cortisol secretion (Louis et al. 1976) and can induce parturition (Young et al. 1996a; Wood 1999; Wood \& Saoud 1997) in this species. Conversely, inhibition of prostaglandin synthesis delays activation of the fetal HPAA (Unno et al. 1998b; McKeown et al. 2000; Gersting et al. 2008). The effect is likely above the level of the pituitary because hypothalamic disconnection severely mutes the response (Young et al. 1996b). If estradiol and/or prostaglandin E2 are key elements acting in the hypothalamus to activate the HPAA, as the results of some studies suggest, the cellular targets and mechanisms have yet to be identified.

The involvement of neurosteroids in modulating the physical activity of the ovine fetus in utero has been convincingly demonstrated (Nicol et al. 2001) and the potential for regulating the HPAA has been suggested (Conley \& Assis Neto 2008; Brunton et al. 2014). Some of the most compelling data are those of Yawno et al. (Yawno et al. 2009), who showed that inhibition of $5 \alpha$-reductase activity by carotid infusion of the enzyme inhibitor finasteride induced an immediate increase in fetal cortisol concentration. Finasteride has been shown to decrease neurosteroid concentrations in the brain of rats (Mukai et al. 2008), and $\mathrm{GABA}_{\mathrm{A}}$ receptor agonists have been shown to modulate their HPAA (Mikkelsen et al. 2008). Additionally, the increase in fetal cortisol induced by finasteride in the fetal lambs was almost completely blocked by simultaneous infusion of alfaxalone, which is an 11 keto-derivative of the neurosteroid allopregnanolone (Yawno et al. 2009). Allopregnanolone is among the most potent of the GABA receptor modulators (Belelli \& Lambert 2005). It is present in the fetal brain and suppresses fetal arousal (Crossley et al. 1997). Stress increases allopregnanolone concentrations in fetal brain, and concentrations fall at birth (Hirst et al. 2006), suggesting that placental pregnanes may well provide a source of substrate for synthesis locally in the fetal brain. Although concentrations of allopregnanolone are not dependent on the fetal adrenal (Nguyen et al. 2004), it is unclear whether or not fetal adrenal activation or neonatal survival are influenced by circulating or local CNS levels of allopregnanolone. The extent to which placental pregnane synthesis contributes to circulating neurosteroid concentrations or feeds local synthesis in the fetal hypothalamus is unknown. The state of adrenal activation in mice deficient in $5 \alpha$-reductase has not been reported (Mahendroo \& Russell 1999), but allopregnanolone has been shown to suppress the adrenal axis in late pregnant rats (Brunton \& Russell 2011). A mechanistic convergence between or among estradiol, prostaglandin E2 and neurosteroid synthesis in the fetal hypothalamus has not been reported but all are likely modulators of adrenal activation in the fetus.

The involvement of $5 \alpha$-reductase in the parturition cascade may extend beyond the fetal HPAA and have relevance purely in the context of progesterone metabolism and physiological withdrawal. Whether or not fetal adrenal activation is required to initiate birth, and clearly in some species it is not (Novy et al. 1977), maternal progesterone (or progestin) withdrawal is likely a universal requirement across mammals. $5 \alpha$-reduction of progesterone to inactive metabolites (unable to bind or activate PR of that species) may be critically important in some species. Evidence reviewed previously argues that increased steroidogenic enzyme expression and placental estrogen synthesis induced by cortisol cannot impact placental progesterone production significantly because of the large difference in total circulating mass of progestins compared with estrogens (Conley \& Assis Neto 2008). If progesterone withdrawal does not involve decreased synthesis, it must involve increased metabolism to inactive products or changes in receptor or effector pathways (Merlino et al. 2007; Karteris et al. 2006; Mendelson 
\& Condon 2005) instead. The effectiveness of PR receptor antagonists in disrupting pregnancy is variable dependent on stage of pregnancy and species, but can either induce abortion or facilitate the abortifacient effects of prostaglandins in domestic animals (Hoffmann \& Schuler 2000; Shenavai et al. 2012), primates (Baird 1993; Spitz et al. 1996) and rodents (Elger et al. 2000). This argues for a primary role for PR activation in pregnancy. As indicated above, the PR has evolved (Baker \& Uh 2012) to exhibit differential binding and perhaps activation by various pregnanes (Jewgenow \& Meyer 1998; Kontula et al. 1975). Immuno-assays cannot distinguish the various pregnanes, even if their bioactivity was defined in a particular species. In other words, even if measurable, the physiological significance of changes in pregnane concentrations relies on characterization of the bioactivities of these metabolites, and differences in biopotencies among species are to be expected. Progesterone withdrawal, even at a systemic level, cannot be evaluated until these steroids can be measured and their bioactivities are known. If $5 \alpha$-reduction of progesterone generates inactive metabolites, the induction of this enzyme in uterine or placental tissues could well initiate progesterone, or progestin, withdrawal.

The significance of progestin withdrawal may extend beyond species in which placental progesterone secretion is sufficient to maintain pregnancy even to those that are luteal-dependent. Systemic progesterone concentrations decrease dramatically after day 28 of pregnancy in pigs (Robertson \& King 1974), due in part to uterine uptake and presumably metabolism (Magness et al. 1986). This decline continues throughout gestation, and fetal adrenal activation occurs in late gestation (Randall \& Tsang 1986) before there is any evidence of luteolysis. Uterine prostaglandin release is not evident until the day of farrowing (Silver et al. 1979). The increase in prostaglandins, which induces luteolysis, is preceded by a decline in progesterone associated with increasing fetal cortisol and an increase in maternal estrogens (Ford et al. 1998). In goats, the array of progesterone metabolites is large and increases as gestation proceeds (Linzell \& Heap 1968; Sheldrick et al. 1981). Even if prostaglandin release completes luteolysis in pre-partum does, it is preceded by a significant decline in progesterone, consistent with the onset of parturition (Ford et al. 1999; Ford et al. 1998; Ford et al. 1995). Thus, increased pregnane metabolism may provoke progestin withdrawal in goats.

Pregnane metabolism also has been investigated in sheep. Anderson et al (Anderson et al. 1975) demonstrated increased placental 17 $\alpha, 20 \alpha$-dihydroxypregn-4-ene-3-one in late gestation, which increased in maternal plasma after dexamethasone administration (Flint et al. 1975). Related $3 \alpha, 20 \alpha$ - and $17 \alpha, 20 \alpha$-dihydroxylated metabolites have been identified in late gestation bovine fetuses (Janowski 1994). In contrast, others have reported that $5 \alpha$-reduction was the major route of progesterone metabolism during pregnancy in ewes (Tsang \& Hackett 1979). The major phenotype of mice lacking $5 \alpha$-reductase type 1 is a defect in parturition (Mahendroo et al. 1996). If species differ in the source of progesterone or other progestins that maintains pregnancy, the array of metabolites is likely to be broad. However, if $5 \alpha$-reduction of progesterone in the fetal hypothalamus suppresses fetal adrenal activation, but promotes progestin withdrawal in the placenta, the effects of its inhibition or ablation will differ depending on its relative importance in certain species. Inhibition of $5 \alpha$-reductase would promote premature parturition if the fetal HPAA, freed of suppression by neurosteroids, activates and can initiate birth, consistent with Yawno et al (Yawno et al. 2009). Conversely, 5 $\alpha$-reductase inhibition would delay parturition if $5 \alpha$-reduction of progesterone is an important route of progestin withdrawal in the placenta and uterus (Fig. 2). Finasteride, a potent $5 \alpha$-reductase inhibitor, induced parturition in mares even though systemic DHP concentrations were not decreased and progesterone was increased by treatment (Ousey et al. 2001). Conversely, we reported that finasteride treatment prolonged gestation in spotted hyenas (Conley \& Assis Neto 2008), but no effect was seen on gestation length in rats (Mann 2006). However, we have shown recently that fetal hypothalamic $5 \alpha$-reductase type $1 \mathrm{mRNA}$ can be up-regulated by maternal melatonin treatment (Reynolds et al. 2013) and that both $5 \alpha$-reductase 


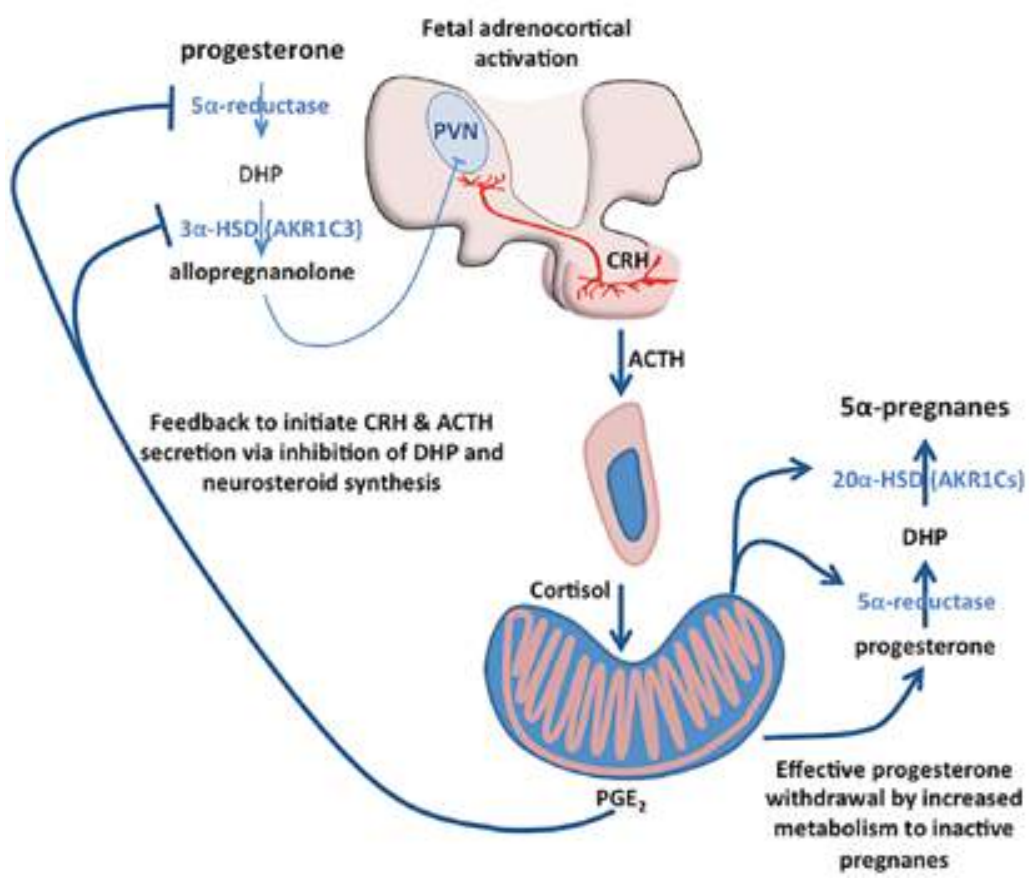

Fig. 2. Diagrammatic representation of the hypothesized involvement of $5 \alpha$-reductase enzyme activity in the physiology of parturition. Prepartum, $5 \alpha$-reductase activity is high in the fetal hypothalamus (paraventricular nucleus, PVN) resulting in production of inhibitory neurosteroids such as allopregnanolone that suppress the HPA axis; at the same time $5 \alpha$-reductase activity is low in the placenta. At parturition, PGE2 from the placenta suppresses $5 \alpha$-reductase activity in fetal hypothalamus, resulting in low levels of inhibitory neurosteroids and activation of the fetal HPA axis; simultaneously, $5 \alpha$-reductase activity in the placenta increases, resulting in metabolism of progesterone to $5 \alpha$-pregnanes and effective progesterone withdrawal (in sheep, for example, DHP binds the progesterone receptor low affinity (Jewgenow \& Meyer 1998). Top, fetal hypothalamus and pituitary; middle, fetal adrenal; bottom, placentome.

type 1 and 2 are expressed at 3- to 4-fold greater levels in term placenta of sheep (LP Reynolds, AJ Conley, PP Borowicz \& JS Caton, unpublished observations). The induction of $5 \alpha$-reductase type 1 expression in sheep placenta by melatonin is particularly intriguing, because it suggests that the gene can be regulated, and in women and non-human primates (Jolly 1972) as well as in mares (Rossdale \& Short 1967), labor most often occurs at night. Even though this is not the case in sheep (Lindahl 1964), there is still a nocturnal increase in melatonin in pregnant ewes and their fetuses (Yellon \& Longo 1987).

\section{Summary and conclusions}

As a final note, neurosteroid synthesis is dependent on the continued metabolism of DHP to metabolites by $3 \alpha$-reduction, whereas oxidative metabolism of progesterone or DHP via $20 \alpha$ - or $20 \beta$-hydroxylation is presumed to generate inactive metabolites. All of these reactions can be catalyzed by aldo-keto reductases (particularly those of the $1 \mathrm{C}$ family), which can also catalyze the synthesis of prostaglandins (Penning 1999). The aldo-keto reductases represent a large family of isozymes (Hyndman et al. 2003; Penning et al. 1997), and although they may be identified presumptively (and annotated) by transcript sequence, their activities are unlikely 
to be totally conserved across species. Nevertheless, they have been implicated in the timing of parturition (Byrns 2011). More importantly perhaps, they also represent a potential metabolic cross-road of steroid and prostanoid conversion (Fig. 3), and may play an especially pivotal role therefore in both progesterone withdrawal and prostanoid-stimulated uterine contractility. An increase in AKR1C expression might accelerate the metabolism of progesterone and the synthesis of prostaglandin, for instance. Alternatively, if substrate availability of one pathway were to increase markedly, the increased competition for available enzyme might decrease metabolism through the other pathway. The possible involvement of AKR1C isozymes in both prostanoid and pregnane metabolism is of both great interest and potential significance. In addition, as noted, we have detected substantial levels of AKR1C3 mRNA during late pregnancy in sheep fetal hypothalamic and placental tissues that can be regulated (Reynolds et al. 2013). What role (s) these play in fetal preparation for birth and initiation of parturition, however, remains to be defined.

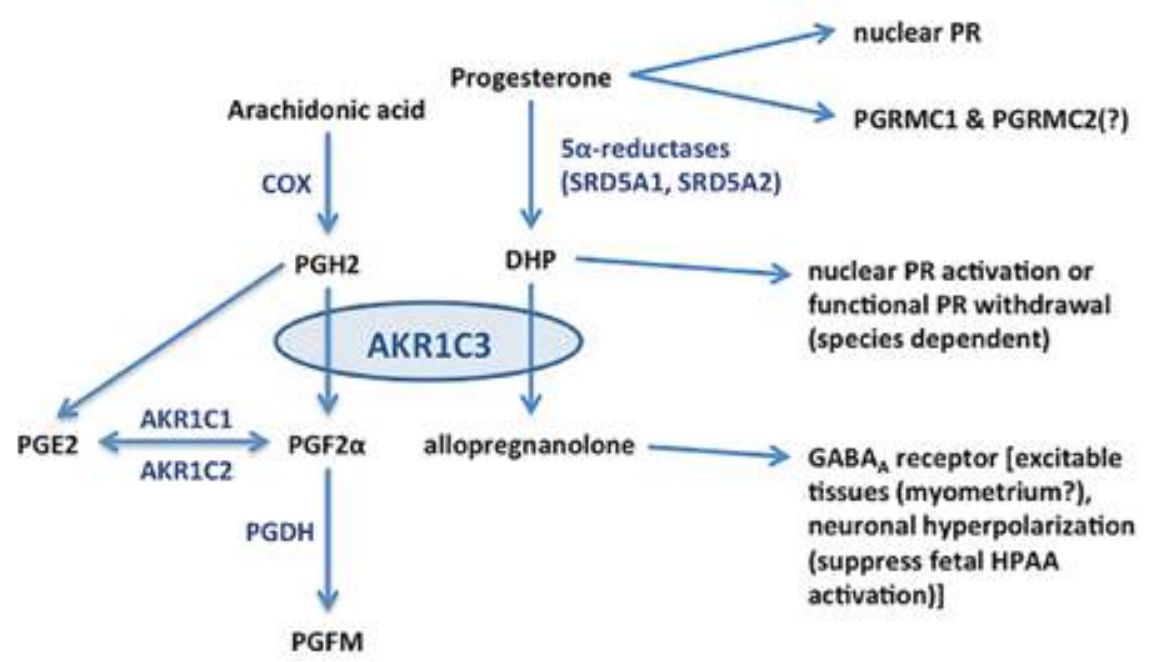

Fig. 3. Diagrammatic representation of prostanoid (modified in part from Dozier et al. 2008) and progesterone pathways of metabolism, potentially linked by aldo-ketoreductase $1 C$ (AKR1C1/2/3) isozymes shown, together with cyclo-oxygenase (COX) and 5 $\alpha$-reductase (SRD5A1/2) isozymes and prostaglandin dehydrogenase (PGDH), shown in blue. The AKR1C3 isozyme potentially acts as a central regulator of myometrial contractility and fetal HPAA activity via its ability to convert DHP to its $3 \alpha$-reduced metabolite, allopregnanolone, which is a potent gamma-aminobutyric acid (GABA) type A receptor agonist and thus hyperpolarizes excitable tissues and neurons. AKR1C3 also is able to convert PGH2 directly to PGF $2 \alpha$, and thus one alternative name for the enzyme is PGF synthase. See text for further explanation. Abbreviations: $\mathrm{AKR}=$ aldo-ketoreductase; $\mathrm{COX}=$ cyclo-oxygenase; $\mathrm{DHP}=$ dihydroprogesterone; GABA - gamma-aminobutyric acid; HPAA = hypothalamic-pituitary-adrenal axis; PG = prostaglandin; PGDH $=$ prostaglandin dehydrogenase; $\mathrm{PGFM}=\mathrm{PGF}$ metabolite; $\mathrm{PGRMC}=$ progesterone receptor membrane component; $\mathrm{PR}=$ progesterone receptor; SRD5A = steroid $5 \alpha$-reductase.

\section{Acknowledgments}

The authors wish to acknowledge their colleagues (Drs. Joel Caton, Anna Grazul-Bilska, Dale Redmer and Kimberly Vonnahme, North Dakota State University, and Dr. Caleb Lemley, Mississippi State University) who helped to generate, and allowed the use of, unpublished data 
referred to in this manuscript, and others who provided feedback and insight on drafts during preparation (Dr. Ian Bird, University of Wisconsin-Madison).

\section{References}

Anderson AB, Flint AP \& Turnbull AC 1975 Mechanism of action of glucocorticoids in induction of ovine parturition: effect on placental steroid metabolism. Journal of Endocrinology 66 61-70.

Astwood EB 1939 An assay method for progeserone based upon the decidual cell reaction in the rat. Journal of Endocrinology 1 49-55.

Baird DT 1993 Antigestogens. British Medical Bulletin 49 73-87.

Baker ME 1997 Steroid receptor phylogeny and vertebrate origins. Molecular and Cellular Endocrinology 135 101-107.

Baker ME 2001 Adrenal and sex steroid receptor evolution: environmental implications. Journal of Molecular Endocrinology 26 119-125.

Baker ME \& Uh KY 2012 Evolutionary analysis of the segment from helix 3 through helix 5 in vertebrate progesterone receptors. The Journal of Steroid Biochemistry and Molecular Biology 132 32-40.

Behrman HR 1988 The history of hormone assays. Progress in Clinical and Biological Research 285 1-14.

Beier-Hellwig K, Kramer H, Bonn B, Linder D, Bader H \& Beier HM 1995 Partial sequencing and identification of three proteins from equine uterine secretion regulated by progesterone. Reproduction in Domestic Animals 30 295-298.

Belelli D \& Lambert JJ 2005 Neurosteroids: endogenous regulators of the GABA (A) receptor. Nature Reviews Neuroscience 6 565-575.

Bernauer S, Wehling M, Gerdes D \& Falkenstein E 2001 The human membrane progesterone receptor gene: genomic structure and promoter analysis. DNA Sequence 12 13-25.

Brooks AN, Power LA, Jones SA, Yang KP \& Challis JR 1989 Controls of corticotrophin-releasing factor output by hypothalamic tissue from fetal sheep in vitro. Journal of Endocrinology 122 15-22.

Brunton PJ \& Russell JA 2011 Allopregnanolone and suppressed hypothalamo-pituitary-adrenal axis stress responses in late pregnancy in the rat. Stress. 14 6-12.

Brunton PJ, Russell JA \& Hirst JJ 2014 Allopregnanolone in the brain: Protecting pregnancy and birth outcomes. Progress in Neurobiology 113 106-136.

Brussaard AB, Wossink J, Lodder JC \& Kits KS 2000 Progesterone-metabolite prevents protein kinase C-dependent modulation of gamma-aminobutyric acid type A receptors in oxytocin neurons. Proceedings of the National Academy of Sciences USA 97 3625-3630.

Byrns MC 2011 Role of aldo-keto reductase enzymes in mediating the timing of parturition. Frontiers in Pharmacology 292.

Challis JR, Dilley SR, Robinson JS \& Thorburn GD 1976 Prostaglandins in the circulation of the fetal lamb.
Prostaglandins 11 1041-1052.

Chavatte-Palmer P, Duchamp G, Palmer E, Ousey JC, Rossdale PD \& Lombes M 2000 Progesterone, oestrogen and glucocorticoid receptors in the uterus and mammary glands of mares from mid- to late gestation. Journal of Reproduction and Fertility Supplement 661-672.

Comline RS, Hall LW, Lavelle RB, Nathanielsz PW \& Silver M 1974 Parturition in the cow: endocrine changes in animals with chronically implanted catheters in the foetal and maternal circulations. Journal of Endocrinology 63 451-472.

Conley AJ \& Assis Neto AC 2008 The ontogeny of fetal adrenal steroidogenesis as a prerequisite for the initiation of parturition. Experimental and Clinical Endocrinology \& Diabetes 16 385-392.

Conley AJ, Rainey WE \& Mason JI 1994 Ontogeny of steroidogenic enzyme expression in the porcine conceptus. Journal of Molecular Endocrinology 12 155-165.

Corner GW 1946 The Hormones in Human Reproduction.

Corner GW \& Allen WM 1929 Physiology of the corpus luteum II. Production of a special uterine reaction (progestational proliferation) by extracts of the corpus luteum. American Journal of Physiology 88 326-339.

Crossett B, Allen WR \& Stewart F 1996 A 19 kDa protein secreted by the endometrium of the mare is a novel member of the lipocalin family. Biochemical Journal. 320 ( Pt 1) 137-143.

Crossett B, Suire S, Herrler A, Allen WR \& Stewart F 1998 Transfer of a uterine lipocalin from the endometrium of the mare to the developing equine conceptus. Biology of Reproduction 59 483-490.

Crossley KJ, Nicol MB, Hirst JJ, Walker DW \& Thorburn GD 1997 Suppression of arousal by progesterone in fetal sheep. Reproduction, Fertility \& Development 9 767-773.

CSAPO A 1956 Progesterone block. Americal Journal of Anatomy 98 273-291.

Csapo Al \& Takeda H 1965 Effect of progesterone on the electric activity and intrauterine pressure of pregnant and parturient rabbits. American Journal of Obstetrics \& Gynecology. 91 221-231.

Dozier BL, Watanabe K \& Duffy DM 2008 Two pathways for prostaglandin F2 alpha synthesis by the primate periovulatory follicle. Reproduction 136 53-63.

Elger W, Bartley J, Schneider B, Kaufmann G, Schubert G \& Chwalisz K 2000 Endocrine pharmacological characterization of progesterone antagonists and progesterone receptor modulators with respect to PRagonistic and antagonistic activity. Steroids 65 713-723.

Fang X, Wong S \& Mitchell BF 2002 Messenger RNA for progesterone receptor isoforms in the late-gestation rat uterus. American Journal of Physiology - Endocrinology \& Metabolism 283 E1167-E1172. 
Flint AP, Goodson JD \& Turnbull AC 1975 Increased concentrations of 17alpha, 20alpha-dihydroxypregn-4en-3-one in maternal and foetal plasma near parturition in sheep. Journal of Endocrinology 67 89-97.

Ford MM, Thorburn GD, Caddy DJ \& Young IR 1999 Pulsatile output of prostaglandin F (2alpha) does not increase around the time of luteolysis in the pregnant goat. Biology of Reproduction 61 411-415.

Ford MM, Young IR, Caddy DJ \& Thorburn GD 1998 Fetal and maternal endocrine changes approaching parturition in the goat: lack of evidence for prostaglandins E2 and F2alpha as signals for luteolysis. Biology of Reproduction 58 1065-1070.

Ford MM, Young IR \& Thorburn GD 1995 Prostaglandins and the maintenance of pregnancy in goats. Journal of Reproduction \& Fertility Supplement 49 555-559.

Fowden AL, Harding R, Ralph MM \& Thorburn GD 1987 The nutritional regulation of plasma prostaglandin $\mathrm{E}$ concentrations in the fetus and pregnant ewe during late gestation. Journal of Physiology 394 1-12.

Geisert RD \& Conley AJ 1998 Secretion and metabolism of steroids in subprimate mammals during pregnancy. In The Endocrinology of Pregnancy, pp. 291-318. Ed FW Bazer. New Jersey: Humana Press Inc.

Gersting J, Schaub CE, Keller-Wood M \& Wood CE 2008 Inhibition of brain prostaglandin endoperoxide synthase-2 prevents the preparturient increase in fetal adrenocorticotropin secretion in the sheep fetus. Endocrinology 149 4128-4136.

Glasser SR 1975 A molecular bioassay for progesterone and related compounds. Methods in Enzymology 36 456-465.

Glickman JA \& Challis JR 1980 The changing response pattern of sheep fetal adrenal cells throughout the course of gestation. Endocrinology 106 1371-1376.

Goto M, Piper HK, Marcos J, Wood PJ, Wright S, Postle AD, Cameron IT, Mason JI, Wilson DI \& Hanley NA 2006 In humans, early cortisol biosynthesis provides a mechanism to safeguard female sexual development. Journal of Clinical Investigation 116 953-960.

Greyling MD, Vanaarde RJ \& Potgieter HC 1997 Ligand specificity of uterine oestrogen and progesterone receptors in the subadult African elephant, Loxodonta africana. Journal of Reproduction and Fertility 109 199-204.

Griffin JE, McPhaul MJ, Russell DW \& Wilson JD 2001 The androgen resistance syndromes: Steroid 5alpha-reductase 2 deficiency, testicular feminization, and related disorders. In The Metabolic and Molecular Basis of Inherited Disease, pp. 4117-4146. New York: McGraw-Hill.

Guerriero G 2009 Vertebrate sex steroid receptors: evolution, ligands, and neurodistribution. Annals of the New York Academy of Sciences 1163 154-168.

Hamon M, Clarke SW, Houghton E, Fowden AL, Silver M, Rossdale PD, Ousey JC \& Heap RB 1991 Production of 5 alpha-dihydroprogesterone during late pregnancy in the mare. Journal of Reproduction and Fertility Supplement 44 529-535.

Haning RV, Jr., Tantravahi U, Zhao Q, Hackett RJ \& Canick JA 1996 5alpha-reductase 1 and 2 expression and activity in human ovarian follicles, stroma and corpus luteum as compared to neonatal foreskin. Journal of Steroid
Biochemistry \& Molecular Biology 59 199-204.

Hill M, Bicikova M, Parizek A, Havlikova H, Klak J, Fajt T, Meloun M, Cibula D, Cegan A, Sulcova J, Hampl R \& Starka L 2001 Neuroactive steroids, their precursors and polar conjugates during parturition and postpartum in maternal blood: 2. Time profiles of pregnanolone isomers. Journal of Steroid Biochemistry \& Molecular Biology 78 51-57.

Hill M, Cibula D, Havlikova H, Kancheva L, Fait T, Kancheva R, Parizek A \& Starka L 2007 Circulating levels of pregnanolone isomers during the third trimester of human pregnancy. Journal of Steroid Biochemistry \& Molecular Biology 105 166-175.

Hirst JJ, Yawno T, Nguyen P \& Walker DW 2006 Stress in pregnancy activates neurosteroid production in the fetal brain. Neuroendocrinology 84 264-274.

Hodges JK, Heistermann M, Beard A \& van Aarde RJ 1997 Concentrations of progesterone and the 5 alpha-reduced progestins, 5 alpha-pregnane-3,20-dione and 3 alphahydroxy-5 alpha-pregnan-20-one, in luteal tissue and circulating blood and their relationship to luteal function in the African elephant, Loxodonta africana. Biology of Reproduction 56 640-646.

Hoffmann B \& Schuler G 2000 Receptor blockers - general aspects with respect to their use in domestic animal reproduction. Animal Reproduction Science 60-61 295-312.

Holtan DW, Houghton E, Silver M, Fowden AL, Ousey J \& Rossdale PD 1991 Plasma progestagens in the mare, fetus and newborn foal. Journal of Reproduction and Fertility Supplement 44 517-528.

Holtan DW, Nett TM \& Estergreen VL 1975 Plasma progestagens in pregnant mares. Journal of Reproduction and Fertility Supplement 419-424.

Hyndman D, Bauman DR, Heredia VV \& Penning TM 2003 The aldo-keto reductase superfamily homepage. Chemico-Biological Interactions 143-144 621-631.

Imperato-McGinley J \& Zhu YS 2002 Androgens and male physiology the syndrome of 5alpha-reductase-2 deficiency. Molecular \& Cellular Endocrinology 198 51-59.

Janowski T 1994 Gestagens in peripheral, uterine, ovarian and fetal blood in cows near term. Experimental \& Clinical Endocrinology 102 193-194.

Jewgenow K \& Meyer HH 1998 Comparative binding affinity study of progestins to the cytosol progestin receptor of endometrium in different mammals. General \& Comparative Endocrinology 110 118-124.

Jolly A 1972 Hour of birth in primates and man. Folia Primatol. (Basel) 18 108-121.

Karteris E, Zervou S, Pang Y, Dong J, Hillhouse EW, Randeva HS \& Thomas P 2006 Progesterone signaling in human myometrium through two novel membrane $G$ protein-coupled receptors: potential role in functional progesterone withdrawal at term. Molecular Endocrinology 20 1519-1534.

Kendrick JW, Kennedy PC \& Stormont C 1957 Adenohypophyseal aplasia, an inherited defect associated with abnormal gestation in Guernsey cattle. The Cornell Veterinarian 47 160-178.

Kirkman S, Wallace ED, van Aarde RJ \& Potgieter HC 2001 
Steroidogenic correlates of pregnancy in the rock hyrax (Procavia capensis). Life Sciences 68 2061-2072.

Klima F, Rohleder M, Dehnhard M \& Meyer HHD 1999 Identification of progesterone and 5 alphadihydroprogesterone ( 5 alpha-DHP) in zebras by two-dimensional high-performance liquid chromatography and their dependence on the state of reproduction. Zoo Biology 18 325-333.

Knobbe MG, Maenhoudt C, Turner RM \& McDonnell SM 2011 Physical, behavioral, endocrinologic, and cytogenetic evaluation of two Standardbred racehorses competing as mares with an intersex condition and high postrace serum testosterone concentrations. Journal of the American Veterinary Medical Association. 238 751-754.

Kontula K, Janne O, Vihko R, de JE, de VJ \& Zeelen F 1975 Progesterone-binding proteins: in vitro binding and biological activity of different steroidal ligands. Acta Endocrinol. (Copenh) 78 574-592.

Leng G \& Russell JA 1999 Coming to term with GABA. Journal of Physiology 516 (Pt 2) VI.

Levy MA, Brandt M, Sheedy KM, Holt DA, Heaslip JI, Trill JJ, Ryan PJ, Morris RA, Garrison LM \& Bergsma DJ 1995 Cloning, expression and functional characterization of type 1 and type 2 steroid 5 alpha-reductases from Cynomolgus monkey: comparisons with human and rat isoenzymes. Journal of Steroid Biochemistry \& Molecular Biology 52 307-319.

Liggins GC \& Kennedy PC 1968 Effects of electrocoagulation of foetal lamb hypophysis on growth and development. Journal of Endocrinology 40 371-381.

Liggins GC, Kennedy PC \& Holm LW 1967 Failure of intiation of parturition after electrocoagulation of pituitary of fetal lamb. American Journal of Obstetrics and Gynecology 98 1080-1086.

Liggins GC \& Thorburn GD 1994 Initiation of parturition. In Marshall's Physiology of Reproduction, pp. 863-1002. Ed GE Lamming. London: Chapman \& Hall.

Lindahl IL 1964 Time of parturition in ewes. Animal Behaviour 12 231-234.

Linzell JL \& Heap RB 1968 A comparison of progesterone metabolism in the pregnant sheep and goat: sources of production and an estimation of uptake by some target organs. Journal of.Endocrinology 41 433-438.

Lofgren M \& Backstrom T 1994 Continuous progesterone exposure associated with high contraction frequency in human term myometrial strips. Acta Obstet.Gynecol. Scand. 73 186-191.

Lofgren M, Holst J \& Backstrom T 1992 Effects in vitro of progesterone and two 5 alpha-reduced progestins, 5 alpha-pregnane-3,20-dione and 5 alpha-pregnane-3 alpha-ol-20-one, on contracting human myometrium at term. Acta Obstet.Gynecol.Scand. 71 28-33.

Losel RM, Falkenstein E, Feuring M, Schultz A, Tillmann HC, Rossol-Haseroth K \& Wehling M 2003 Nongenomic steroid action: controversies, questions, and answers. Physiological Reviews 83 965-1016.

Louis TM, Challis JR, Robinson JS \& Thorburn GD 1976 Rapid increase of foetal corticosteroids after prostaglandin E2. Nature 264 797-799.

Magness RR, Reynolds LP \& Ford SP 1986 Evidence for uterine metabolism of progesterone during early pregnancy in the pig. Theriogenology 25 551-558.

Mahendroo MS, Cala KM, Landrum DP \& Russell DW 1997 Fetal death in mice lacking 5alpha-reductase type 1 caused by estrogen excess. Molecular Endocrinology 11 917-927.

Mahendroo MS, Cala KM \& Russell DW 19965 alphareduced androgens play a key role in murine parturition. Molecular Endocrinology 10 380-392.

Mahendroo MS, Porter A, Russell DW \& Word RA 1999 The parturition defect in steroid 5alpha-reductase type 1 knockout mice is due to impaired cervical ripening. Molecular Endocrinology 13 981-992.

Mahendroo MS \& Russell DW 1999 Male and female isoenzymes of steroid 5alpha-reductase. Reviews of Reproduction 4 179-183.

Majewska MD \& Vaupel DB 1991 Steroid control of uterine motility via gamma-aminobutyric acidA receptors in the rabbit: a novel mechanism? Journal of Endocrinology 131 427-434.

Mann PE 2006 Finasteride delays the onset of maternal behavior in primigravid rats. Physiology \& Behaviour 88 333-338.

Marshall FHA 1922 The Physiology of Reproduction.

McKeown KJ, Challis JR, Small C, Adamson L, Bocking AD, Fraser M, Rurak D, Riggs KW \& Lye SJ 2000 Altered fetal pituitary-adrenal function in the ovine fetus treated with RU486 and meloxicam, an inhibitor of prostaglandin synthase-II. Biology of Reproduction 63 1899-1904.

McPhail MK 1934 The assay of progestin. Journal of Physiology 83 145-156.

Mendelson CR 2009 Minireview: fetal-maternal hormonal signaling in pregnancy and labor. Molecular Endocrinology 23 947-954.

Mendelson CR \& Condon JC 2005 New insights into the molecular endocrinology of parturition. Journal of Steroid Biochemistry \& Molecular Biology 93 113-119.

Merlino AA, Welsh TN, Tan H, Yi LJ, Cannon V, Mercer BM \& Mesiano S 2007 Nuclear progesterone receptors in the human pregnancy myometrium: evidence that parturition involves functional progesterone withdrawal mediated by increased expression of progesterone receptor-A. Journal of Clinical Endocrinology and Metabolism 92 1927-1933.

Mesiano S 2004 Myometrial progesterone responsiveness and the control of human parturition. Journal of the Society for Gynecologic Investigation 11 193-202.

Meyer HHD, Jewgenow K \& Hodges JK 1997 Binding activity of 5 alpha-reduced gestagens to the progestin receptor from African elephant (Loxodonta africana). General and Comparative Endocrinology 105 164-167.

Mikkelsen JD, Bundzikova J, Larsen MH, Hansen HH \& Kiss A 2008 GABA regulates the rat hypothalamic-pituitaryadrenocortical axis via different GABA-A receptor alpha-subtypes. Annals of the New York Academy of Sciences 1148 384-392.

Milewich L, Gant NF, Schwarz BE, Chen GT \& MacDonald PC 1979 5-Alpha-Reductase Activity in Human-Placenta. American Journal of Obstetrics and Gynecology 133 611-617.

Milewich L, Gomez-Sanchez C, Madden JD \& MacDonald PC 1975 Isolation and characterization of 5alphapregnane-3,20-dione and progesterone in pepipheral 
blood of pregnant women. measurement throughout pregnancy. Gynecologic and Obstetric Investigation 6 291-306

Milewich L, Mendonca BB, Arnhold I, Wallace AM, Donaldson MDC, Wilson JD \& Russell DW 1995 Women with Steroid 5-Alpha-Reductase-2 Deficiency Have Normal Concentrations of Plasma 5-AlphaDihydroprogesterone During the Luteal-Phase. Journal of Clinical Endocrinology \& Metabolism 80 3136-3139.

Mueller-Heubach E, Myers RE \& Adamsons K 1972 Effects of adrenalectomy on pregnancy length in the rhesus monkey. American Journal of Obstetrics \& Gynecology. 112 221-226.

Mukai Y, Higashi T, Nagura Y \& Shimada K 2008 Studies on neurosteroids XXV. Influence of a 5alpha-reductase inhibitor, finasteride, on rat brain neurosteroid levels and metabolism. Biological \& Pharmaceutical Bulletin 31 1646-1650.

Muller-Schottle F, Bogusz A, Grotzinger J, Herrler A, Krusche CA, Beier-Hellwig K \& Beier HM 2002 Fulllength complementary DNA and the derived amino acid sequence of horse uteroglobin. Biology of Reproduction. 66 1723-1728.

Nguyen PN, Ross Y, I, Walker DW \& Hirst JJ 2004 Allopregnanolone in the brain and blood after disruption of the hypothalamic-pituitary-adrenal axis in fetal sheep. Journal of Endocrinology 182 81-88.

Nicol MB, Hirst J] \& Walker DW 2001 Effect of finasteride on behavioural arousal and somatosensory evoked potentials in fetal sheep. Neuroscience Letters 306 13-16.

Novy MJ, Walsh SW \& Kittinger GW 1977 Experimental fetal anencephaly in the rhesus monkey: effect on gestational length and fetal and maternal plasma steroids. Journal of Clinical Endocrinology and Metabolism 45 1031-1038.

Ousey J, Palmer L, Grainger L, Houghton E \& Fowden A 2001 Effect of 5alpha-reductase blockade on progestagen metabolism and parturition in mares. Reproduction Supplement

Ousey JC, Forhead AJ, Rossdale PD, Grainger L, Houghton E \& Fowden AL 2003 Ontogeny of uteroplacental progestagen production in pregnant mares during the second half of gestation. Biology of Reproduction 69 540-548.

Ousey JC, Freestone N, Fowden AL, Mason WT \& Rossdale PD 2000 The effects of oxytocin and progestagens on myometrial contractility in vitro during equine pregnancy. Journal of Reproduction \& Fertilility Supplement $\mathbf{5 6}$ 681-691.

Ousey JC, Houghton E, Grainger L, Rossdale PD \& Fowden AL 2005 Progestagen profiles during the last trimester of gestation in Thoroughbred mares with normal or compromised pregnancies. Theriogenology 63 18441856.

Parizek A, Hill M, Kancheva R, Havlikova H, Kancheva L, Cindr J, Paskova A, Pouzar V, Cerny I, Drbohlav P, Hajek Z \& Starka L 2005 Neuroactive pregnanolone isomers during pregnancy. Journal of Clinical Endocrinology and Metabolism 90 395-403.

Penning TM 1999 Molecular determinants of steroid recognition and catalysis in aldo-keto reductases. Lessons from 3alpha-hydroxysteroid dehydrogenase. Journal of Steroid Biochemistry \& Molecular Biology 69 211-225.

Penning TM, Bennett MJ, Smith-Hoog S, Schlegel BP, Jez JM \& Lewis M 1997 Structure and function of 3 alphahydroxysteroid dehydrogenase. Steroids 62 101-111.

Perusquia M \& Jasso-Kamel J 2001 Influence of 5alpha- and 5beta-reduced progestins on the contractility of isolated human myometrium at term. Life Sciences 68 2933-2944.

Putnam CD, Brann DW, Kolbeck RC \& Mahesh VB 1991 Inhibition of uterine contractility by progesterone and progesterone metabolites: mediation by progesterone and gamma amino butyric acidA receptor systems. Biology of Reproduction 45 266-272.

Rahman SS, Billiar RB \& Little B 1975 Induction of uteroglobin in rabbits by progestogens, estradiol-17 beta and ACTH. Biology of Reproduction 12 305-314.

Randall GC \& Tsang BK 1986 Influence of the fetal pituitaryadrenal axis on fetal and maternal progesterone and unconjugated oestrogen concentrations in the pig. Journal of Reproduction \& Fertility 78 65-72.

Reddy DS 2003 Pharmacology of endogenous neuroactive steroids. Critical Reviews in Neurobiology 15 197-234.

Reynolds LP, Borowicz PP, Johnson ML, Haring J, Asley R \&Grazul-Bilska AT 2012a Expression of sex steroid receptors in placental tissues during early pregnancy in sheep. Journal of Animal Science 90[Supplement 3], 570.

Reynolds LP, Caton JS, Borowicz PP, Vonnahme KA, Lemley CO \& Conley AJ 2013 Maternal melatonin treatment alters expression of fetal hypothalamic 5á-reductase type 1. Pediatric Research 74, 479-483.

Reynolds LP, Johnson ML, Haring J, Asley R, Borowicz PP, Redmer DA \& Grazul-Bilska AT 2012b Expression of sex steroid receptors in ovine placental tissues during early pregnancy: Effects of assisted reproductive technologies (ART). Annual Meeting of the Society for the Study of Reproduction State College, PA[Proceedings], 380.

Robertson HA \& King GJ 1974 Plasma concentrations of progesterone, oestrone, oestradiol-17beta and of oestrone sulphate in the pig at implantation, during pregnancy and at parturition. Journal of Reproduction \& Fertility 40 133-141.

Rossdale PD \& Short RV 1967 The time of foaling of thoroughbred mares. Journal of Reproduction \& Fertility 13 341-343.

Ruddock NK, Shi SQ, Jain S, Moore G, Hankins GD, Romero R \& Garfield RE 2008 Progesterone, but not 17-alpha-hydroxyprogesterone caproate, inhibits human myometrial contractions. American Journal of Obstetrics \& Gynecology 199 391-397.

Russell DW \& Wilson JD 1994 Steroid 5 alpha-reductase: two genes/two enzymes. Annual Review of Biochemistry 63 25-61.

Scholtz EL, Krishnan S, Ball BA, Corbin CJ, Moeller BC, Stanley SD, McDowell KJ, Hughes AL, McDonnell DP \& Conley AJ 2014 Pregnancy without progesterone in horses defines a second endogenous biopotent progesterone receptor agonist, 5alpha-dihydroprogesterone. Proceedings of the National Academy of Sciences USA.

Sheldrick EL, Ricketts AP \& Flint AP 1981 Placental production of 5 beta-pregnane- 3 alpha,20 alpha-diol in 
goats. Journal of Endocrinology 90 151-158.

Shenavai S, Preissing S, Hoffmann B, Dilly M, Pfarrer C, Ozalp GR, Caliskan C, Seyrek-Intas K \& Schuler G 2012 Investigations into the mechanisms controlling parturition in cattle. Reproduction. 144 279-292.

Short RV 1959 Progesterone in blood. IV. Progesterone in the blood of mares. Journal of Endocrinology 19 207-210.

Silver M, Barnes RJ, Comline RS, Fowden AL, Clover L \& Mitchell MD 1979 Prostaglandins in the fetal pig and prepartum endocrine changes in mother and fetus. Animal Reproduction Science 2 305-322.

Silver M \& Fowden AL 1989 Pituitary-adrenocortical activity in the fetal pig in the last third of gestation. Quarterly Journal of Experimental Physiology \& Cognate Medical Sciences 74 197-206.

Silver M \& Fowden AL 1994 Prepartum adrenocortical maturation in the fetal foal: responses to ACTH. Journal of Endocrinology 142 417-425.

Slonina D, Kowalik MK \& Kotwica J 2012 Expression of progesterone receptor membrane component 1, serpine mRNA binding protein 1 and nuclear progesterone receptor isoforms $\mathrm{A}$ and $\mathrm{B}$ in the bovine myometrium during the estrous cycle and early pregnancy. Journal of Reproduction \& Development 58 288-294.

Spitz IM, Croxatto HB \& Robbins A 1996 Antiprogestins: mechanism of action and contraceptive potential. Annual Review of Pharmacology \& Toxicology. 36 47-81.

Stormont C, Kendrick JW \& Kennedy PC 1956 A New Syndrome of Inherited Lethal Defects Associated with Abnormal Gestation in Guernsey Cattle. Genetics 41663.

Stryker JL \& Dziuk PJ 1975 Effects of fetal decapitation on fetal development, parturition and lactation in pigs. Journal of Animal Science 40 282-287.

Thorburn GD, Hollingworth SA \& Hooper SB 1991 The trigger for parturition in sheep: fetal hypothalamus or placenta? Journal of Developmental Physiology 15 71-79.

Tsang CP \& Hackett AJ 1979 Metabolism of progesterone in the pregnant sheep near term: identification of 3 betahydroxy-5 alpha-pregnan-20-one 3-sulfate as a major metabolite. Steroids 33 577-588.

Unno N, Wu WX, Ding XY, Li C, Hing WK \& Nathanielsz PW 1998a The effects of fetal adrenalectomy at 110 days gestational age on AVP and CRH mRNA expression in the hypothalamic paraventricular nucleus of the ovine fetus. Brain Research. Developmental Brain Research 106 119-128.

Unno N, Wu WX, Wong CH, Bennett PR, Shinozuka N \& Nathanielsz PW 1998b Prostaglandin regulation of fetal plasma adrenocorticotropin and cortisol concentrations in late-gestation sheep. Biology of Reproduction $\mathbf{5 8}$ 514-519.

Wagner GP, Tong Y, Emera D \& Romero R 2012 An evolutionary test of the isoform switching hypothesis of functional progesterone withdrawal for parturition: humans have a weaker repressive effect of PR-A than mice. Journal of Perinatal Medicine. 40 345-351.

Wei LL, Krett NL, Francis MD, Gordon DF, Wood WM, O'Malley BW \& Horwitz KB 1988 Multiple human progesterone receptor messenger ribonucleic acids and their autoregulation by progestin agonists and antagonists in breast cancer cells. Molecular Endocrinology 2 62-72.

Wierer M, Schrey AK, Kuhne R, Ulbrich SE \& Meyer HH 2012 A single glycine-alanine exchange directs ligand specificity of the elephant progestin receptor. PLoS.One. 7 e50350.

Wilson JD 1975 Metabolism of testicular androgens. In Endocrinology, pp. 491-508. Eds DW Hamilton \& RO Greep. Washington CD: American Physiological Society.

Wilson JD 2001 The role of 5alpha-reduction in steroid hormone physiology. Reproduction, Fertilility \& Development 13 673-678.

Wilson JD, Griffin JE \& Russell DW 1993 Steroid 5 alphareductase 2 deficiency. Endocrine Reviews 14 577-593.

Wintour EM, Brown EH, Denton DA, Hardy KJ, McDougall JG, Oddie CJ \& Whipp GT 1975 The ontogeny and regulation of corticosteroid secretion by the ovine foetal adrenal. Acta Endocrinol. (Copenh) 79 301-316.

Wood CE 1999 Control of parturition in ruminants. Journal of Reproduction \& Fertility Supplement 54 115-126.

Wood CE 2005 Estrogen/hypothalamus-pituitary-adrenal axis interactions in the fetus: The interplay between placenta and fetal brain. Journal of the Society for Gynecologic Investigation 12 67-76.

Wood CE \& Saoud CJ 1997 Influence of estradiol and androstenedione on ACTH and cortisol secretion in the ovine fetus. Journal of the Society for Gynecologic Investigation 4 279-283.

Yawno T, Hirst J, Castillo-Melendez M \& Walker DW 2009 Role of neurosteroids in regulating cell death and proliferation in the late gestation fetal brain. Neuroscience 163 838-847.

Yellon SM \& Longo LD 1987 Melatonin rhythms in fetal and maternal circulation during pregnancy in sheep. American Journal of Physiology 252 E799-E802.

Young IR, Deayton JM, Hollingworth SA \& Thorburn GD 1996a Continuous intrafetal infusion of prostaglandin E2 prematurely activates the hypothalamo-pituitary-adrenal axis and induces parturition in sheep. Endocrinology 137 2424-2431.

Young IR, Loose JM, Kleftogiannis F \& Canny BJ 1996b Prostaglandin E2 acts via the hypothalamus to stimulate ACTH secretion in the fetal sheep. Journal of Neuroendocrinology 8 713-720.

Zhu Y, Rice CD, Pang Y, Pace M \& Thomas P 2003 Cloning, expression, and characterization of a membrane progestin receptor and evidence it is an intermediary in meiotic maturation of fish oocytes. Proceedings of the National Academy of Sciences USA 100 2231-2236. 
